\title{
MINING
}

UDC $622.274 .3: 622.831$

M. I. Stupnik, Dr. Sc. (Tech.), Prof., V. O. Kalinichenko, Dr. Sc. (Tech.), Prof., orcid.org/0000-0002-1938-2286,

M. B. Fedko, Cand. Sc. (Tech.), Assoc. Prof., orcid.org/0000-0003-4169-7425,

O.V. Kalinichenko, Cand. Sc. (Econ.), Assoc. Prof., orcid.org/0000-0002-9138-9271
DOI: $10.29202 /$ nvngu/2018-6/5

State Institution of Higher Education "Kryvyi Rih National University”, Kryvyi Rih, Ukraine, e-mail: prrkk@mail.ru

\section{INVESTIGATION INTO CROWN STABILITY AT UNDERGROUND LEACHING OF URANIUM ORES}

Purpose. Determination of influence of various factors on crown stability at underground block leaching of uranium ores.

Methodology. Mathematical modeling applying the finite element and analytical methods is used to investigate into the impact of the ore body dip angle and crown workings on changes in the crown stress-strain state and stability. On this basis, dependencies of the above factors' influence on the crown stability are determined enabling their adequate consideration when specifying the appropriate crown thickness. Laboratory studies allow estimating influence of the reagent used at block leaching of uranium ores on their hardness for the purposes of determining safe crown parameters.

Findings. The dependencies of the ore body dip angle impact and the degree of crown disturbances caused by workings on crown stability as well as uranium ore hardness decrease resulted from application of the acid solution enable adjusting the appropriate crown thickness in determining safe parameters of the technology at the stage of the design work execution.

Originality. Scientific novelty consists in determining dependencies that consider the impact of the ore body dip angle and the degree of crown disturbances caused by workings on crown stability. For the first time, influence of the sulfuric acid solution used in underground block leaching of uranium ores on changes in their hardness has been studied. Comprehensive consideration of the effect of these factors and the determined dependencies enables specifying safe thickness of crowns and ensures their integrity.

Practical value. Possibility of adjusting crown thickness considering the ore body dip angle, the degree of disturbance caused by workings, and the acid solution impact will allow specifying the appropriate crown thickness at the stage of designing. This will allow avoiding possible failure of crowns caused by negative impacts of the above factors and ensuring safety of works.

Keywords: uranium ores, underground block leaching, stress-strain state, stability, crown parameters

Introduction. Due to very complicated morphology of occurrence, mining uranium ores at the State Enterprise "SkhidGZK" underground mines by room-andpillar methods which are the traditional for the current conditions with further backfilling of dead areas is characterized by high costs and is economically viable for deposits with higher uranium content.

Mining lean uranium-containing ores is most advisable to be performed from both economic and environmental points of view applying the underground block leaching technology which consists in shrinkage stoping, treating the muck with sulphuric acid solution and then harvesting the uranium saturated PR solution. Af-

(C) Stupnik M. I., Kalinichenko V. O., Fedko M. B., Kalinichenko O. V., 2018 ter the sorptive extraction of the useful component the concentrated solution is taken to a hydrometallurgical works. Due to this technology, a number of laborious and environmentally hazardous operations are excluded from the technological chain. On the one hand, this results in maximum yield of the useful component and, on the other hand, helps to avoid considerable material expenditures for preparing the backfill mixture and filling dead stopes (which is common for the traditional technology as when applying underground block leaching, a stope is almost completely filled with the shrunken ore) as well as for disposal of waste rocks and off-balance ores.

To decrease expenditures on the above technology implementation in relevant conditions it is rational to 
place another room under the one filled with muck and separate it from the above lying room by a temporary crown pillar. Protected by this pillar, a compensating room can be created in the block below, and filled with the muck of the block reserve. After that the temporary crown pillar can be caved for further leaching of uranium ores with sulphuric acid solution supplied from the workings above the upper block room.

As this technology is distinctly different from the traditional one, primarily from the point of view of stress fields development in both major construction units and the surrounding rocks, the temporary crown is disturbed by workings and affected by reagents used in underground block leaching, the problem of studying the processes and their impact on crown stability gains significance.

Analysis of the recent research and publications. Determining safe parameters of exposures and pillars when applying the room-and-pillar systems in mining is performed in accordance with corresponding instructions $[1,2]$ for uranium mines of the SE "SkhidGZK" and iron ore mines of Kryvbas. However, the instructions consider only changes of the stress-strain state (SSS) and, correspondingly, stability depending on the dip angle of exposures (vertical, horizontal or inclined), and do not take into account impacts of dip angles of ore bodies when determining safe parameters of pillars. However, effects of this factor are obvious. On the basis of his research Prof. S. H. Borysenko (Borisenko, S. G., Komskyi, Ye. I.) suggested determining minimum permissible dimensions of pillars considering not only loads affecting the pillar and physical and mechanical properties of the ore, but also the ore body dip through introduction of a corresponding correction factor. Results of more detailed research into impacts of a dip on the SSS of crowns are given in [3, 4]. But these research studies were conducted in relation to iron ore mines of Kryvbas that significantly differ in both hardness of ores and enclosing rocks and values of pressure impacting a crown.

Influence of the degree of disturbance of crowns (pillars, in particular) on their stability is dealt with in [5] where it is also suggested to consider this applying a corresponding correction factor whose value mainly depends on the number of workings in the pillar.

As for the chemical reagent used in underground block leaching of uranium ores (a sulphuric acid solution of certain concentration), there are no studies of this kind as this technology is relatively new to Ukraine. The globally spread hole leaching of various types of useful minerals (including uranium ores) is a different technology in principle.

Unsolved aspects of the problem. The current instructions determining permissible dimensions of major construction units when applying room-and-pillar systems either do not consider influence of dip angles and a degree of pillar disturbance caused by workings on their stability (though, as the analysis of the research studies and publications show, this degree is rather significant and requires consideration) or are not designed for determining safe crown thickness. This is absolutely true for the instructions [1] that are applied at the SE "SkhidGZK" underground mines, as the technology of underground block leaching of uranium ores is new to the mines and requires scientific support. As for the impact of the sulfuric acid solution on uranium ores hardness, there is no research on the problem at all.

The investigation is aimed at determining impacts of various factors (an ore body dip, a degree of disturbance of a crown caused by workings and the effect of the sulphuric acid solution on it) on crown stability when applying the technology of uranium ores underground block leaching with mining by vertical double blocks.

Presentation of the main research. Influence of an ore body dip angle on the stress-strain state and stability of crowns was studied through modeling the process and applying the finite-element method. The investigations were bound to specific conditions of the "Inhulska" underground mine, namely ore body 10 of Michurinske deposit for blocks $10-2$ and 10-3 which are located within survey axes $86-90+7$ at the level 325-184 m where the technology of underground block leaching is to be used. When modeling the process, the uranium ore hardness ratio varied from 9-11 to $14-16$ on the Protodyakonov scale, that of the enclosing rocks $-13-15$, the ore body dip made from 60 to $90^{\circ}$ (in increments of $10^{\circ}$ ). The changes of the stress-strain state were registered in crowns of 10 to $14 \mathrm{~m}$ thick. For calculating the stress field characteristics Ansys 18 was used.

Figs. 1, 2 and 3 exemplify results of modeling the stress-strain state of $10 \mathrm{~m}$ thick crowns of ores of various hardness with the ore body dip angles of 90,70 and $60^{\circ}$.

As the figures show, the tension stress zone in the lower central part of the crown is the most dangerous. This corresponds to the classical concepts of stress field development in the so called "stress relief arch" that occurs when the massif is undermined by the lower block room. Under the same conditions (equal crown thickness and ore body dip) absolute values of stress in the crown decrease slightly (by $0.1 \ldots 0.5 \mathrm{MPa}$, i.e. from $1 \ldots 2$ to $6 . .7 \%$ ). This can be explained by the fact that weaker ores are less capable of accumulating stress as they get relieved through deforming towards a free surface (i. e. a room) and, on the contrary, harder ores tend to accumulate stress due to smaller deformations. However, stability of weaker ore crowns decreases due to reduction of their ultimate strength.

For instance, with the ore body dip angle $\alpha=90^{\circ}$ and hardness of 14-16 points, the value of tension stress in the lower part of the crown reaches 10.1 MPa (Fig. 1, a). However, ultimate strength of such ores is about $11 \mathrm{MPa}$, these stresses will not cause failures. When the crown is made of ores of 10-11 points (Fig. 1, d), the tension stress level makes 9.9 $\mathrm{MPa}$. With the ultimate tensile strength of the ores of 7.7 MPa this will cause rock falls of about $100 \ldots 150 \mathrm{~m}^{3}$ (according to "Instructions..." used at "SkhidGZK" mines [1], rock falls of over $250 \ldots 300 \mathrm{~m}^{3}$ are considered critical). With the dip angle $\alpha=70^{\circ}$ and ores of $14-16$ points crown failures hardly occur (Fig. 2, $a$ ), with $\alpha=60^{\circ}$ small rock falls $\left(3-5 \mathrm{~m}^{3}\right)$ may occur even in crowns of ores of the same hardness (Fig. 3, a). In crowns of ores of 10-11 points with 



$c$
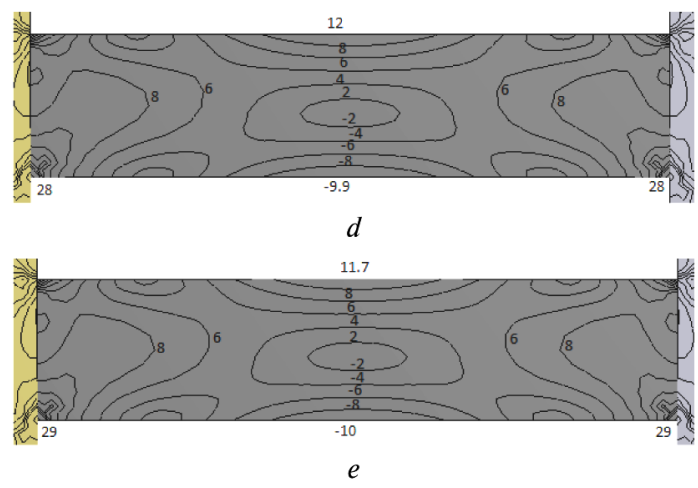

Fig. 1. Stress field development in $10 \mathrm{~m}$ crowns with the ore body dip of $90^{\circ}(\mathrm{MPa})$ :

$a-e-$ the crown of ores of $14-16,13-15,11-13,10-11$ and 9 points respectively

$\alpha=70^{\circ}$ (Fig. 2, $b$ ) and $\alpha=60^{\circ}$ (Fig. 3, $b$ ) the volume of rock falls will make from 150 to $200 \ldots 220 \mathrm{~m}^{3}$, sometimes to $400 \ldots 450 \mathrm{~m}^{3}$ respectively. These values testify to the critical condition of the crown at angles about $\alpha=70^{\circ}$, at about $\alpha=60^{\circ}$ the crown will fail.

Thus, the obtained results testify to the considerable impact of the ore body dip angle on the stress-strain state of crowns and their stability. On the basis of the research conducted, to be sensitive to this impact we suggest applying the correction factor $K_{\alpha}$, whose numer-
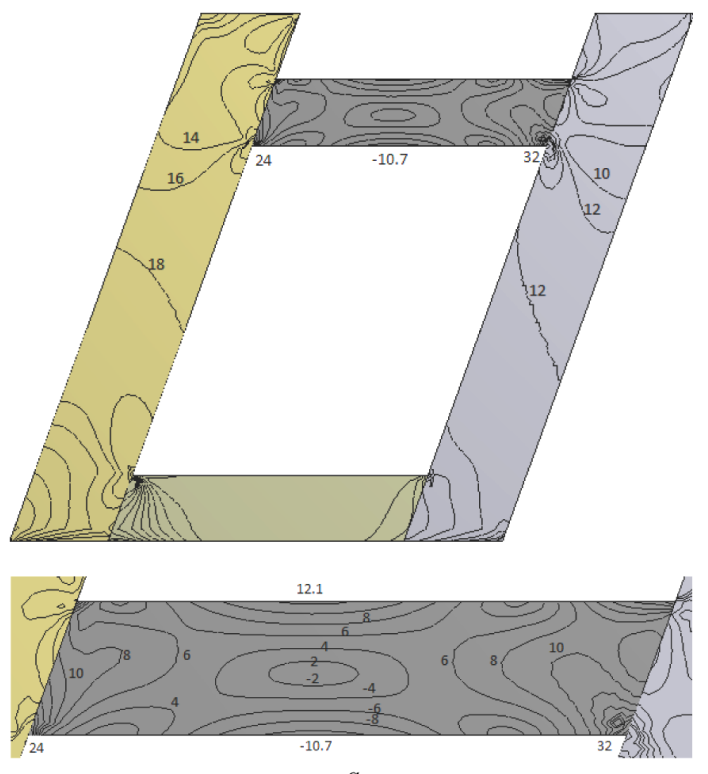

$a$

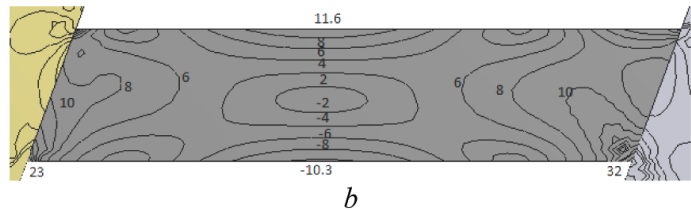

Fig. 2. Stress field development in $10 \mathrm{~m}$ crowns with the ore body dip of $70^{\circ}, \mathrm{MPa}$ :

$a-b-$ the crown of ores of 14-16 and 10-11 points respectively
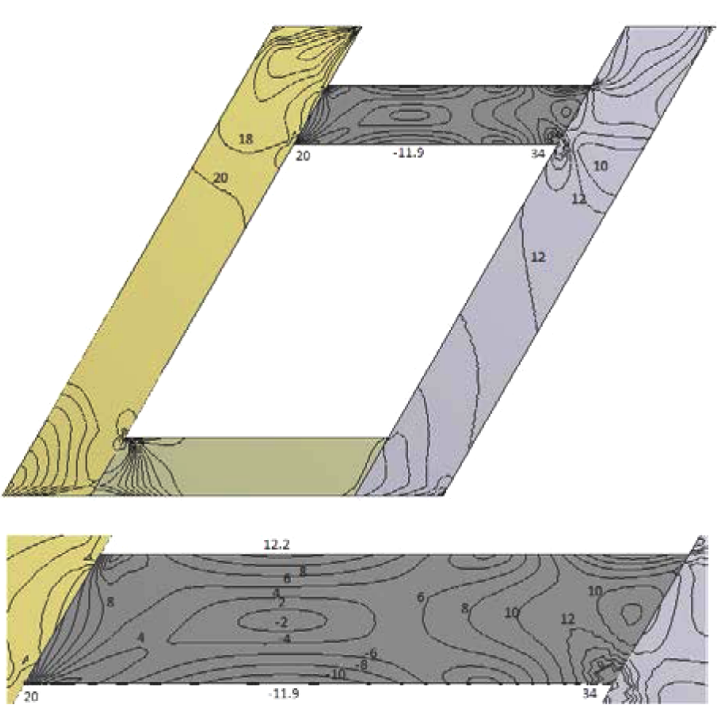

$a$

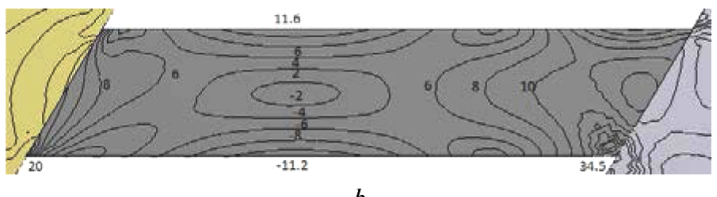

Fig. 3. Stress field development in $10 \mathrm{~m}$ crowns with the ore body dip of $60^{\circ}, \mathrm{MPa}$ :

$a-b-$ the crown of ores of $14-16$ and 10-11 points respectively 
ical values are given in Fig. 5. So, when determining the minimum permissible thickness of the crown in particular conditions, its value obtained without this factor should be corrected through multiplying it by a corresponding value $K_{\alpha}$.

As to the impact of workings in a crown on changes in its SSS, it is a well-known fact that any workings in rocks result in changes in the initial stress fields to the distance three times as large as the size of the working. Due to it, when determining dimensions of exposures and pillars and their technological parameters, they are corrected by relating them to a relevant stage of the room mining order according to their conditions (e.g. as stipulated in NIGRI instructions [2]) or applying a relevant correction factor to initial, so to say standard, conditions (as suggested in [3]).

Similarly, we suggest correcting thickness of the crown $h_{c r}^{n}$ disturbed by workings using the expression, $\mathrm{m}$

$$
h_{c r}^{n}=h_{c r} \cdot K_{d i s t}
$$

where $h_{c r}$ is thickness of the undisturbed crown, m; $K_{\text {dist }}$ is the factor considering the degree of the crown disturbance resulted from mining, unit fraction.

As the disturbance degree of the crown depends on the number of workings in it, their geometrical dimensions (height in particular) both of each of them individually and the general thickness of the crown, we suggest determining the numerical value of $K_{\text {dist }}$ as the product of individual factors $K$, each of them differentially taking into account the impact of each working in the crown, as follows, unit fraction

$$
K_{\text {dist }}=K_{1} \cdot K_{2} \cdot \ldots \cdot K_{n},
$$

where $n$ is the number of workings in the crown.

Numerical values of these factors calculated individually for each working can tentatively be determined as follows

$$
K_{i}=\sqrt{1+\left(h_{i}^{w} / h_{c m}\right)},
$$

where $h_{i}^{w}$ is the $i^{\text {th }}$ working height (width), m.

For instance, with the necessary (minimum permissible) thickness of the crown not disturbed by workings $h_{c r}=10 \mathrm{~m}$ and with workings of $2.5,3.0,3.5$ and $4.0 \mathrm{~m}$, the correction factors for each of them will equal 1.12, 1.14, 1.16 and 1.18 respectively. That is, the crown thickness must be increased to $11.2,11.4,11.6$ and $11.8 \mathrm{~m}$, respec-

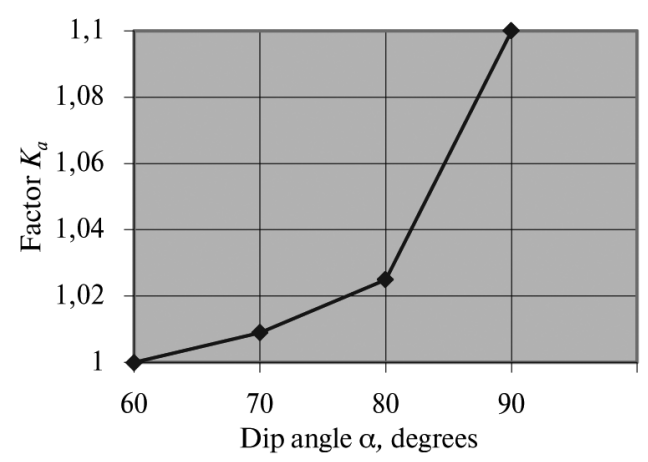

Fig. 4. $K_{\alpha}$ values depending on ore body dip angle $\alpha$ tively. If there are 2 workings of 3.0 and $3.5 \mathrm{~m}$ in the crown, the correction factor will make $K_{\text {dist }}=1.14 \cdot 1.16=$ $=1.32$ and correspondingly, the disturbed crown thickness should make $13.2 \mathrm{~m}$. In case of 3 workings of $2.5,3.0$ and $3.5 \mathrm{~m}$ in the crown, the correction factor will make $K_{\text {dist }}=1.12 \cdot 1.14 \cdot 1.16=1.48$ and under such conditions the crown thickness should be half as much and make $14.8 \mathrm{~m}$.

Thus, considering the existing conditions in a mining block the crown thickness can be corrected by the value of its decreased stability due to its current workings that weaken it and, in doing so, avoid its possible failure.

One of the main components of underground block leaching of uranium ores is shrinkage stoping with further sulphuric acid treatment. When placing another room under the one filled with muck and separating it from the latter by a temporary crown pillar, the crown will be affected by the sulphuric acid solution. Based in the data on the physical and mechanical properties of rocks of Michurinske deposit provided by the engineers of the SE "SkhidGZK", the authors assume that the longstanding (from 3-4 to 6 months) exposure to the sulphuric acid may negatively impact strength of the ore massif which forms "the body" of the crown. According to the above mentioned data, the average compressive resistance of rocks, e. g. albitites and migmatites, in their natural humidity conditions and when water-saturated makes 164.4 and 127.5 MPa for albitites and 153.1 and 112.4 MPa for migmatites, respectively. That is, if compared with the natural state, water saturation of rocks reduces their compressive resistance by $22 . . .27 \%$.

To confirm or deny the impact of the sulphuric acid solution on the crown stability the authors conducted the following investigation. Forty ore cubes with $50 \mathrm{~mm}$ sides were divided into two groups. The first group of 10 cubes was used to determine strength in the natural conditions (that is not affected by the sulphuric acid solution), the remaining cubes were used for determining the degree of the sulphuric acid solution impact on their strength. To keep natural conditions and provide conditions of the ore contacting the acid solution, only one face of an ore sample contacted the acid solution, the other faces of the cubes being covered with two coatings of paraffin. The other group of cubes was placed in a vessel with the sulphuric acid solution which is used for spraying the shrunk muck in underground mines of the SE "SkhidGZK". To determine the impact of the exposing time on the uranium ore strength, the second group was tested 2.5, 4 and 6 months after dipping that corresponds to the minimum and maximum time of the reagent impact in real conditions.

The laboratory bench for the research was equipped with a hydraulic press able to produce pressure up to $50 \mathrm{t}$, i. e. in relation to the cubes' surface $S=25 \mathrm{~cm}^{2}$ the corresponding pressure makes about $2000 \mathrm{~kg} / \mathrm{cm}^{2}$, or $200 \mathrm{MPa}$. The press is coupled with a computer that sets the loading rate for the samples and forms the loading diagram for each of the samples with the automatic recording of the current load and maximum pressure at the moment of their destruction. During the tests the minimum loading rate of $1 \mathrm{kN} / \mathrm{s}$ was set according to corresponding standards (from 1 to $5 \mathrm{kN} / \mathrm{s}$ ). 
Tests of the first group of the samples demonstrated that the average value of the uniaxial compressive resistance made about $128 \mathrm{MPa}$ that is, according to the instructions [6], corresponds to the rock hardness ratio of 11 points. For 10 samples exposed to the sulphuric acid solution during 2.5 , the average value made about $82 \mathrm{MPa}$ (according to [6], this corresponds to rocks with the hardness ration of 8 points), i. e. their strength decreased by $36 \%$. Tests of the samples exposed to the solution during 4 months showed further decrease in their strength by $5 \%$ (to $79 \%$ ). That is, in general, strength decrease made $38.5 \%$. Strength of the samples exposed to the sulphuric acid solution during 6 months decreased to $77 \mathrm{MPa}$, i.e. it decreased by $40 \%$ as compared with the uniaxial compressive resistance values of the first group samples.

Thus, the performed investigations confirmed our assumption about the considerable impact of the acid solution on the hardness of uranium ores treated by it and on stability of exposures and pillars (crowns, in particular). That will, no doubt, influence the stability of exposures (rocks) and pillars. This factor must be considered in defining the safe crown thickness when applying the technology of underground block leaching of uranium ores.

Conclusions. Thus, the investigation conducted enabled determining the degree of impact of the ore body dip, the degree of the ore body disturbance by workings and the acid solution effects when applying underground block leaching of uranium ores. These factors must be considered when determining safe dimensions of crowns and exposures by applying corresponding correction factors. As a result, in particular conditions of mining blocks this will enable correcting the crown thickness by the value of its stability decrease caused by unfavorable factors, and thus avoiding the crown failure and providing safety of works. The determined dependencies can then be corrected considering practical experience of the SE "SkhidGZK" underground mines.

\section{References.}

1. GP "UkrNIPIIpromtekhnologii, 2014. Instructions for substantiating safe and stable parameters of stopes at underground mines of SE "VostGOK”. Zheltye Vody.

2. Babets, Ye. K., Sakovych, V., Syrotik, S. and Tsarykovskyi, V., 2010. Determination and control of permissible dimensions of structural units of iron ore mining systems. Instructions for use. Kryvyy Rih: DP "NIGRI”.

3. Khomenko, O. E. and Tsenzhav, L., 2013. Technology of development of uranium deposits in Mongolia by the method of borehole underground leaching. National Mining University. Zbirnik naukovyh prat., 42, pp. 74-80. 4. Ahrens, V.Zh., ed., 2010. Physico-chemical geotechnology: Monograph. Moscow: MSU Publishing House. 5. Stupnik, N. I., Kalinichenko, V. A., Fedko, M. B. and Mirchenko, E. G., 2013. Influence of the stress-strain state of the rock massif on the technology of breaking uranium ores. Naukovyi Visnyk Natsionalnoho Hirnychoho Universytetu, 2, pp. 11-16.

6. NIGRI GUVZ KNU, 2012. Instructions for determining rock stability in mining at uranium deposits. Krivoy Rog: "NIGRI GUVZ KNU".
7. Kuz'menko, A., Lozynskyi, V., Saik, P., Petlovanyi, M., Sai, K. and Malanchuk, Ye., 2018. Analytical Research of the Stress-Deformed State in the Rock Massif around Faulting. International Journal of Engineering Research in Africa, 35, pp. 77-88.

8. Khomenko, O., Sudakov, A., Malanchuk, Z. and Malanchuk, Ye., 2017. Principles of rock pressure energy usage during underground mining of deposits. Naukovyi Visnyk Natsionalnoho Hirnychoho Universytetu, 2, pp. $35-43$.

9. Kaplenko, Yu. P. and Tsarikovskiy, V. V., 2005. Impact of the rock strain state and mining and geological conditions on exposure parameters and stope shapes. Ore mining, 88, pp. 21-24.

10. Stupnik, N. I., Kalinichenko, V.A. and Kalinichenko Ye. V., 2018. The study of the stress-strain state of the massif in mining uranium at "Vostgok" deposits. Innovative development of resource-saving technologies for mining. Multi-authored monograph. Sofia: Publishing House "St. Ivan Rilski".

11. Stupnik, M.I., Kalinichenko, V. O., Fedko, M. B., Malinovskyi, Yu.O., Kalinichenko, O.V., Pukhalskyi, B. M. and Kryvokhin, B.I., 2018. Defining the crown thickness at underground leaching of uranium ores in mining by vertical double blocks. Bulletin of Kryvyi Rih National University, 46, pp. 3-9.

12. Bondarenko, V. I., Kovalevskaia, I. A. and Vivcharenko, A. V., 2014. Increasing stability of workings in schistous soft rock massif. Ugol Ukrainy, 2, pp. 8-11.

\section{Дослідження стійкості стелин при підземному вилуговуванні уранових руд}

\author{
М. І. Ступнік, В. О. Калініченко, М. Б. Федько, \\ О. В. Калініченко
}

Державний вищий навчальний заклад „Криворізький національний університет“, м. Кривий Ріг, Україна, e-mail:prrkk@mail.ru

Мета. Визначення впливу різних факторів на стійкість стелин при використанні технології підземного блокового вилуговування уранових руд.

Методика. Шляхом математичного моделювання з використанням методу кінцевих елементів та із застосуванням аналітичного методу досліджено вплив кута падіння рудного покладу й пройдених у стелині виробок на змінення іiі напружено-деформованого стану та стійкості. На цій підставі встановлені залежності впливу зазначених факторів на стійкість стелин, що дають можливість адекватно враховувати їх при визначенні необхідної товщини стелини. Лабораторними дослідженнями також встановлена ступінь впливу реагенту, що застосовують при підземному блоковому вилуговуванні уранових руд, на змінення їх міцності, яку також необхідно враховувати при визначенні безпечних параметрів стелин.

Результати. Встановлені залежності впливу кута падіння рудних покладів і ступеня порушеності стелин пройденими виробками на їх стійкість, а також зменшення міцності уранових руд при дії на 
них кислотного розчину, дають можливість скоригувати необхідну товщину стелини при визначенні безпечних параметрів даної технології на етапі виконання проектних робіт.

Наукова новизна. Полягає у встановленні залежностей, що враховують вплив кута падіння рудного покладу та ступеня порушеності стелин виробками на стійкість стелин. Уперше досліджено вплив розчину сірчаної кислоти, що застосовується при підземному блоковому вилуговуванні уранових руд, на змінення їх міцності. Комплексне врахування дії цих факторів із використанням встановлених залежностей дає можливість визначати безпечну товщину стелин і гарантуватиме їх цілісність.

Практична значимість. Можливість коригування товщини стелини з урахуванням кута падіння рудного покладу, ступеня порушеності пройденими виробками, дії кислотного розчину дозволить на етапі виконання проектних робіт визначити необхідну їі товщину. Це дасть нагоду уникнути можливого руйнування стелини від негативної дії вищезазначених факторів і забезпечити безпеку робіт.

Ключові слова: уранові руди, підземне блокове вилуговування, напружено-деформований стан, стійкість. параметри стелини

\section{Исследование устойчивости потолочин при подземном выщелачивании урановых руд}

\author{
Н. И. Ступник, В. А. Калиниченко, М. Б. Федько, \\ Е. В. Калиниченко
}

Государственное высшее учебное заведение „Криворожский национальный университет“, г. Кривой Рог, Украина, e-mail: prrkk@mail.ru

Цель. Определение влияния различных факторов на устойчивость потолочин при использовании технологии подземного блочного выщелачивания урановых руд.

Методика. Путем математического моделирования с использованием метода конечных элементов, а также с применением аналитического метода исследовано влияние угла падения рудной залежи и пройденных в потолочине выработок на изменение ее напряженно-деформированного состояния и устойчивости. На этом основании установлены за- висимости влияния указанных факторов на устойчивость потолочин, которые дают возможность адекватно учитывать их при определении необходимой толщины потолочины. Лабораторными исследованиями также установлена степень влияния реагента, который применяют при подземном блочном выщелачивании урановых руд, на изменение их прочности, что также необходимо учитывать при определении безопасных параметров потолочин.

Результаты. Установленные зависимости влияния угла падения рудных залежей и степени нарушенности потолочин пройденными выработками на их устойчивость, а также уменьшения прочности урановых руд при воздействии на них кислотного раствора, дают возможность скорректировать необходимую толщину потолочин при определении безопасных параметров данной технологии на этапе выполнения проектных работ.

Научная новизна. Заключается в установлении зависимостей, учитывающих влияние угла падения рудной залежи и степени нарушенности потолочин выработками, на устойчивость потолочин. Впервые исследовано влияние раствора серной кислоты, применяемого при подземном блочном выщелачивании урановых руд, на изменение их прочности. Комплексный учет воздействия этих факторов с использованием установленных зависимостей дает возможность определять безопасную толщину потолочин и обеспечить их целостность.

Практическая значимость. Возможность корректировки толщины потолочины с учетом угла падения рудной залежи, степени нарушенности пройденными выработками, действия кислотного раствора, позволит на этапе выполнения проектных работ определить необходимую ее толщину. Это даст возможность избежать возможного разрушения потолочины от негативного воздействия вышеупомянутых факторов и обеспечить безопасность работ.

Ключевые слова: урановые руды, подземное блочное выщелачивание, напряженно-деформированное состояние, устойчивость, параметры потолочины

Рекомендовано до публікації докт. техн. наук B. О. Колосовим. Дата надходження рукопису 20.11.17. 